\title{
研究
}

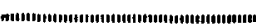

\section{起電力法による $\mathrm{NiW}_{2} \mathrm{~B}_{2}$ の標準生成ギブス 自由エネルギーと $\mathrm{Ni}$-W 2 成分系の活量の測定*}

\author{
香 山 湝一郎**, 橋 本 䔨 彦** \\ 鈴 木 建 次**, 松 尾 英 樹***
}

Koichiro Koyama, Yasuhiko Hashimoto, Kenji Suzuki and Hideki Matsuo: Determination of Standard Gibbs Free Energy of Formation of $\mathrm{NiW}_{2} \mathrm{~B}_{2}$ and Activity of Ni-W Binary System by EMF Measurement.

The standard Gibbs free energy of formation of $\mathrm{NiW}_{2} \mathrm{~B}_{2}$ was determined in the temperature range from $1273 \mathrm{~K}$ to $1423 \mathrm{~K}$ by measuring electromotive forces of a galvanic cell having a solid oxide electrolyte. Also, the standard Gibbs free energies of formation of $\mathrm{WO}_{2}$ and $\mathrm{WO}_{49 / 18}$ and the Gibbs free energy of mixing of the Ni-W binary system, which were necessary to determine the standard Gibbs free energy of formation of $\mathrm{NiW}_{2} \mathrm{~B}_{2}$, were determined. The results obtained are as follows:

(1) $\Delta G^{\circ}{ }_{f}\left(\mathrm{NiW}_{2} \mathrm{~B}_{2}\right)=-199000+3.08 T \pm 1000 \mathrm{~J} / \mathrm{mol} \quad(1273 \sim 1423 \mathrm{~K})$.

(2) $\Delta G_{f}^{\circ}\left(\mathrm{WO}_{2}\right)=-573100+167.0 T \pm 100 \mathrm{~J} / \mathrm{mol} \quad(1223 \sim 1473 \mathrm{~K})$.

(3) $\Delta G^{\circ}{ }_{f}\left(\mathrm{WO}_{49 / 18}\right)=-755400+213.2 T \pm 200 \mathrm{~J} / \mathrm{mol} \quad(1223 \sim 1423 \mathrm{~K})$.

(4) The Gibbs free energy of mixing of the Ni-W solid solution (Ni-16.4 mol\%W), which is in equilibrium with $\mathrm{NiW}_{2} \mathrm{~B}_{2}$, is:

$$
\Delta G_{\mathrm{m}}(\mathrm{Ni}-16.4 \mathrm{~mol} \% \mathrm{~W})=-4040+0.280 T \pm 3 \mathrm{~J} / \mathrm{mol} \quad(1273 \sim 1423 \mathrm{~K}) .
$$

(Received May 18, 1989)

\section{I 緒言}

遷移金属ホウ化物は融点が高く，極好硬く，化学的 に安定であり，また炭化物よりあ酸化抵抗が大きい，こ のため，遷移金属ホウ化物は酎熱，耐食および耐摩耗材 料の構成成分の 1 つして注目されている. 渚者らの研

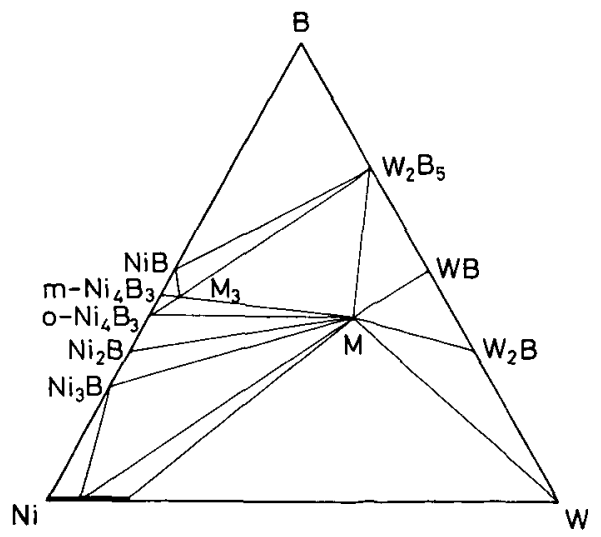

Fig. 1 Phase relationship in Ni-W-B system at $1273 \mathrm{~K}^{\natural)}$. $\mathrm{M}: \mathrm{NiW}_{2} \mathrm{~B}_{2}, \mathrm{M}_{3}$ : NizoWB17.
究室では，これまでに $\mathrm{Ni}_{3} \mathrm{~B}, \mathrm{Ni}_{2} \mathrm{~B}, \mathrm{Co}_{3} \mathrm{~B}, \mathrm{Co}_{2} \mathrm{~B}, \mathrm{Fe}_{3} \mathrm{~B}$, $\mathrm{Fe}_{2} \mathrm{~B}, \mathrm{Mo}_{2} \mathrm{~B}, \mathrm{MoB}, \mathrm{W}_{2} \mathrm{~B}$ および WB の標準生成ギブス 自由エネルギーを, 酸化物固体電解質を用いる起電力法 により測定し，報告した ${ }^{277}$. さらに，前報では8， $\mathrm{Ni}$ $\mathrm{Mo}-\mathrm{B} 3$ 成分系化存在する 3 成分化合物 $\mathrm{NiMO}_{2} \mathrm{~B}_{2}$ の標 準生成ギブス自由エネルギーを，酸化物固体電解質を用 いる起電力法により測定した. 本研究では，Ni-W-B 3 成分系 (Fig. 1 参炤") 亿存在する 3 成分化合物 $\mathrm{NiW}_{2} \mathrm{~B}_{2}$

（以下では M之略記する）の標準生成ギブス自由エネル ギーを，1273〜 $1423 \mathrm{~K}$ の温度籍囲で，酸化物固体電解質 を用いる酸素港淡電池を構成 L, $\mathrm{Ni}$ 固溶体 $(16.4 \mathrm{~mol} \%)$ $-\mathrm{M}-\mathrm{W} 3$ 相之酸化物 $\mathrm{B}_{2} \mathrm{O}_{3}$ 間の平衡酸素分圧を測定する ことにより求めたので報告する.

\section{【実 験 方 法}

Fig. 1 から分加るように, M, W, Ni 固溶体 3 相領域之 平衡する酸化物相が, $\mathrm{B}_{2} \mathrm{O}_{3}$ であるならば，ての3 相領域 内にある試料を用いて，酸化物固体電解質を用いる起電

* 平成元年 5 月 18 日受理.

** 姫路工業大学金属材料工学教室, $7671-22$ 姫路市書写2167.

*** 福伸電機株式会社, T $679-22$ 兵庫県神崎郡福崎町福田. 


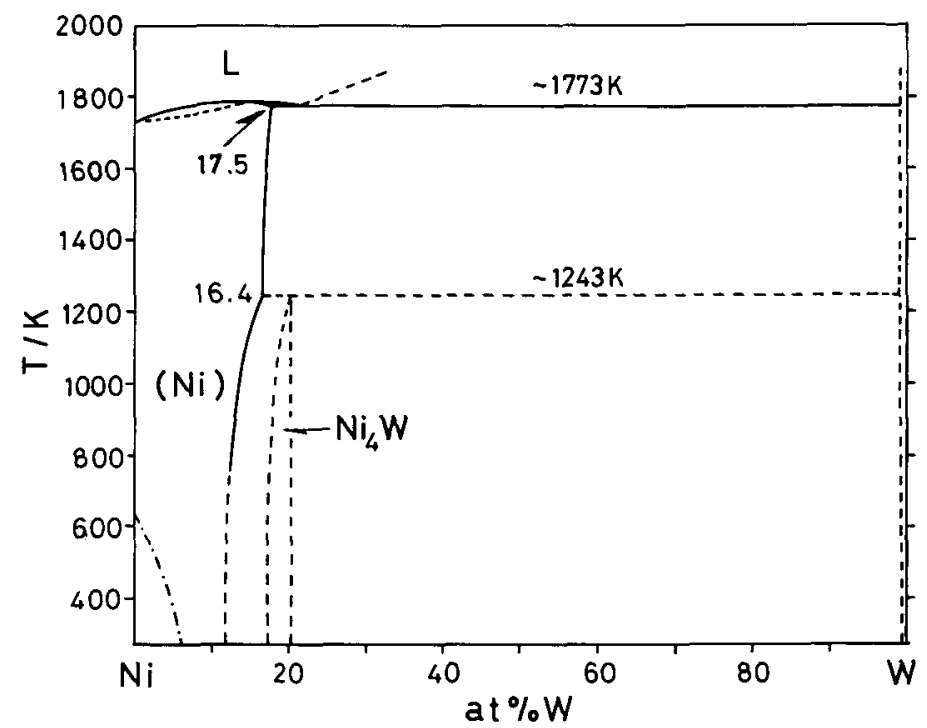

Fig. 2 Phase diagram of $\mathrm{Ni}-\mathrm{W}$ system ${ }^{10)}$.

力法により，M相の標準生成ギブス自由エネルギーを求 めるととができる．測定した起電力より M相の標準生成 ギブス自由エネルギーを計算するためには，M相执よび $\mathrm{W}$ 相と平衡する $\mathrm{Ni}$ 固溶体の混合のギブス自由エネルギ 一の值が必要である．Fig. $2^{10}$ 亿 Ni-W 2 成分系の状態 四を示す，M相およびW相と平衡する $\mathrm{Ni}-\mathrm{W} 2$ 成分系固 溶体の組成は，Fig. 2 から分かるように，1273〜1423 K の温度範囲では実質的に一定であり，それは $\mathrm{Ni}-16.4$ mol $\% \mathrm{~W}$ である．乙の組成の混合のギブス自由エネルギ 一を求めるためには, Ni-W 2 成分系の $\mathrm{Ni}$ 抢よびWの活 量を知る必要がある. Fig. 3 亿 Jakob ${ }^{11}$ による Ni-W$\mathrm{O}$ 系の相関系図を示す. $\mathrm{Ni}-\mathrm{W}$ 固溶体は $\mathrm{WO}_{2}$ または $\mathrm{WO}_{2.72}\left(\mathrm{WO}_{49 / 18}\right)$ と平衡する. したがって, $\mathrm{WO}_{2}$ および $\mathrm{WO}_{2.72}\left(\mathrm{WO}_{49 / 18}\right)$ の標準生成ギブス自由エネルギーの值 が分かっておれば，酸化物固体電解質を用いる起電力法 により， Ni-W 2 成分系のWの活量を測定することがで

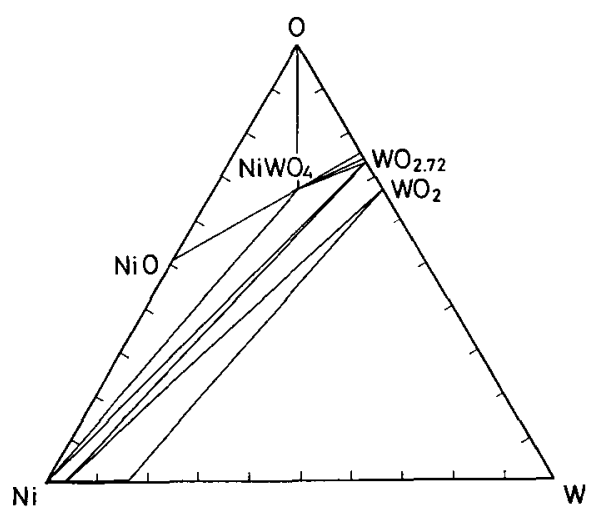

Fig. 3 Phase relationship in Ni-W-O system ${ }^{11}$.
きる. Wの活量が分かれば, Ni の活量は Gibbs-Duhem の式に基づく図皘分により求めるととができる.

したがって，本研究ではまず，M, W, Ni 固溶体 3 相領 域と平衡する酸化物相が， $\mathrm{B}_{2} \mathrm{O}_{3}$ であるてとを確認した 後, $\mathrm{WO}_{2}$ および $\mathrm{WO}_{2.22}\left(\mathrm{WO}_{49 / 18}\right)$ の標準生成ギブス自由 エネルギーの值を求め，つで, Ni-W 2 成分系のWの 活量を測定することにより Ni-16.4 mol\% 固溶体の混合 のギブス自由エネルギーを計算し, 最後に $\mathrm{M}, \mathrm{W}, \mathrm{Ni}$ 固 溶体 3 相領域内にある試料を用いて，起電力法により， M相の標準生成ギブス自由エネルギーを求坖とにし たななお， $\mathrm{WO}_{2}$ の標準生成ギブス自由エネルギーは，片

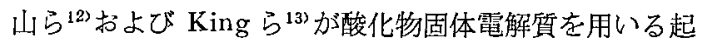
電力法により測定している. $\mathrm{WO}_{49 / 18}$ の標準生成ギブス 自由エネルギーは, Rizzo(4)や Ackerman ${ }^{15)}$ が酸化物固 体電解質を用いる起電力法により測定している，本研究 においても，WO $\mathrm{WO}_{2}$ および $\mathrm{WO}_{49 / 18}$ の標準生成ギブス自 由エネルギーを, 酸化物固体電解質を用いる起電力法に より再測定することにした.

\section{【-1 試料の調製}

試料はつぎの出発物質を用いて作製した：Ni 粉（純 度99.8\%), W粉 (純度99.7\%), B (純度99\%), $\mathrm{WO}_{3}$ (試薬特級). $\mathrm{Ni}$ 粉之W粉については, 粒子表面の酸化物 を還元するために，使用直前纪約 $673 \mathrm{~K}$ で $3.6 \mathrm{ks}$ 間水 菜気流中で処理した. $\mathrm{WO}_{2}$ は $\mathrm{WO}_{3}$ 粉末を水素気流中, $823 \mathrm{~K}$ で $3.6 \mathrm{ks}$ 間保持して作製した。作製した $\mathrm{WO}_{2}$ は，X線回折および重量分析 $\left(\mathrm{WO}_{2}\right.$ を $\mathrm{WO}_{3}$ へ再酸化さ せる）により調べ， $\mathrm{WO}_{2}$ であることを確認した。 $\mathrm{WO}_{49 / 18}$ は, W 粉亡 $\mathrm{WO}_{3}$ 粉を $\mathrm{WO}_{49 / 18}$ の組成になるように配 合し, 正縮成形し (成形圧 $200 \mathrm{MPa}$ ), 乙れを石英管に真 空封入し, $1373 \mathrm{~K}$ で約 $0.9 \mathrm{Ms}$ 間熱処理して作製した。 
作製した $\mathrm{WO}_{49 / 18}$ は，X線回折淿より調へ， $\mathrm{WO}_{49 / 18}$ 以 外の相が含まれていないととを確認した。

M相の標準生成ギブス自由エネルギーを求めるために は, M, W, Ni 固溶体 (16.4 mol\%W) 3 相と平衡する酸化 物相を知る必要がある。これは $\mathrm{B}_{2} \mathrm{O}_{3}$ 亡 $\mathrm{WO}_{2}$ のうちの いずれかであるうと推測される，そこで, M-W-Ni 固溶 体 $-\mathrm{B}_{2} \mathrm{O}_{3} 4$ 面体と $\mathrm{M}-\mathrm{W}-\mathrm{Ni}$ 固溶体 $-\mathrm{WO}_{2} 4$ 面体とが交 差する組成 $(60 \mathrm{~mol} \% \mathrm{Ni}-17.8 \mathrm{~mol} \% \mathrm{~W}-8.9 \mathrm{~mol} / \% \mathrm{~B}-13.3$ $\mathrm{mol} \% \mathrm{O})$ の試料を, $20 \mathrm{~mol} \% \mathrm{Ni}-60 \mathrm{~mol} \% \mathrm{~W}-20 \mathrm{~mol} \% \mathrm{~B} 3$ 成分系合金粉之 $\mathrm{WO}_{2}$ 粉配合後压縮成形し(成形王 200 $\mathrm{MPa}$ ，乙れを石英管に真空封入し，1373 K で約 $1.7 \mathrm{Ms}$ 間熱処理して作製した。これを用いて平衡する酸化物相 の検討を行った。

$\mathrm{Ni}-\mathrm{W} 2$ 成分系合金試料は，所定の組成になるように 配合した $\mathrm{Ni}$ 粉亡W粉を圧縮成形し，アルゴンガス雾囲 気下でタングステン電極を用いてアーク溶解し，得られ た鋳塊をアルゴンガス雾囲気下で $1473 \mathrm{~K}$ で, $1.7 \mathrm{Ms}$ 間 均一化処理し，ついで水焼入れして作製した。 これを棒 状ダイヤモンド碰石を用いて研削して粉末にした．ダイ ヤモンド砥石の合金粉末への混入は 0.1 mass\% 以下で あった。

$\mathrm{M}$ 相の標準生成ギブス自由エネルギーを求めるための 電池の電極物質の組成は, $\mathrm{M}-\mathrm{W}-\mathrm{Ni}$ 固溶体 3 相共存領域 内にあればよい，そこで， $20 \mathrm{~mol} \% \mathrm{Ni}-60 \mathrm{~mol} \% \mathrm{~W}-20$ mol\% B を選び, $\mathrm{Ni}$ 粉, $\mathrm{W}$ 粉标よび $\mathrm{B}$ 粉を出発物犋に用 い, Ni-W 2 成分合金の場合と同じ手法で電極試料を作 製した. 試料粉は，熱処理後の塊状試料をアルミナ製乳 錸中で粉砕して作製した。

作製した試料中の相の確認はX線回折により行った。 $\mathrm{Ni}-\mathrm{W} 2$ 成分合金については，螢光X線分析により組成 分析を行った．配合組成と分析組成上の差は無視できる 程度であった．また，配合質量とアーク溶解後の質量と の差も無視できる程度であったので，配合組成をそのま ま陚料組成として用いることにした。

\section{II -2 電池構成}

$\mathrm{WO}_{2}$ の標準生成ギブス自由エネルギー $\Delta G^{0}{ }_{\mathrm{f}}\left(\mathrm{WO}_{2}\right)$ を 求めるために，つぎの電池表式で表される電池を組み立 てた.

\section{Cell( (I): $\mathrm{Pt}\left|\mathrm{W}, \mathrm{WO}_{2}\right| \mathrm{YSZ}(8) \mid$ air $\mid \mathrm{Pt}$.}

$\mathrm{YSZ}(8)$ は $8 \mathrm{~mol} \%$ の $\mathrm{Y}_{2} \mathrm{O}_{3}$ で安定化した $\mathrm{ZrO}_{2}$ 固体電 解質を意味する。この電池の電池反応は，

$$
\mathrm{W}+\mathrm{O}_{2(\mathrm{air})}=\mathrm{WO}_{2}
$$

である.したがって，YSZ(8) の酸素イオンの輸率が1で あるならば, $\Delta G^{\circ}{ }^{\circ}\left(\mathrm{WO}_{2}\right)$ と電池の起電力 $\mathrm{E}$ との間仙， つぎの関係がある.

$$
\Delta G^{\circ}{ }^{\circ}\left(\mathrm{WO}_{2}\right)=\mathrm{RT} \ln \mathrm{p}_{02(\mathrm{air})}-4 \mathrm{FE} \text {. }
$$

po2(air) は大気中の酸素分近であり，0.20948 atm であ
$3^{(6)}$.

$\mathrm{WO}_{49 / 18}$ の標準生成ギブス自由エネルギー $\Delta G^{\circ}{ }_{1}$

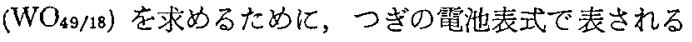
電池を組み立てた。

Cell( II): $\mathrm{Pt}\left|\mathrm{WO}_{49 / 18}, \mathrm{WO}_{2}\right| \mathrm{YSZ}(8) \mid$ air $\mid \mathrm{Pt}$.

この電池の電池反応は,

$$
\mathrm{WO}_{2}+(13 / 36) \mathrm{O}_{2(\mathrm{air})}=\mathrm{WO}_{49 / 18}
$$

である．したがって， $\Delta G^{\circ}\left(\mathrm{WO}_{49 / 18}\right)$ と電池の起電力 $\mathrm{E}$ との間には，つぎの関係がある。

$$
\begin{aligned}
\Delta G^{\circ}{ }_{\mathrm{f}}\left(\mathrm{WO}_{49 / 18}\right) & =\Delta G^{\circ}{ }_{\mathrm{f}}\left(\mathrm{WO}_{2}\right)+ \\
(13 / 36) & \left\{\mathrm{RT} \ln \mathrm{no}_{02}(\mathrm{air})-4 \mathrm{FE}\right\} .
\end{aligned}
$$

$\mathrm{Ni}-\mathrm{W} 2$ 成分系のWの活量を求めるために，つぎの電 池表式で表される 2 種類の電池を組み立てた。

$$
\begin{aligned}
& \text { Cell(II) : Pt }\left|\mathrm{Ni}-\mathrm{W}, \mathrm{WO}_{49 / 18}\right| \mathrm{YSZ}(8) \mid \text { air } \mid \mathrm{Pt} . \\
& \text { Cell(IV) }: \mathrm{Pt}\left|\mathrm{Ni}-\mathrm{W}, \mathrm{WO}_{2}\right| \mathrm{YSZ}(8) \mid \text { air } \mid \mathrm{Pt} .
\end{aligned}
$$

Fig. 3 加ら分かるように, Ni-W 固溶体と平衡する酸化 物は，W濃度が低い場合には $\mathrm{WO}_{49 / 18}$ であり，W 濃度が 高い場合には $\mathrm{WO}_{2}$ である。 その境界のW濃度について は実験結果の䇢所で述べる，上記 Cell (III)，Cell (IV) の電池反応は,

$$
\begin{aligned}
& \mathrm{W}(\text { in Ni-W })+(49 / 36) \mathrm{O}_{2(\text { a i r })}=\mathrm{WO}_{49 / 18} \\
& \mathrm{~W}(\text { in Ni-W })+\mathrm{O}_{2(\text { a i r })}=\mathrm{WO}_{2}
\end{aligned}
$$

である. したがって, Wの活量 $\mathrm{a}_{\mathrm{w}}$ と電池の起電力 $\mathrm{E}$ と の間には，つぎの関係がある。

$$
\begin{aligned}
& \mathrm{RTlna}_{\mathrm{w}}=\Delta G^{\circ} \mathrm{f}\left(\mathrm{WO}_{49 / 18}\right) \\
& -(49 / 36)\left\{\mathrm{RT} \ln _{2(a i r)}-4 \mathrm{FE}\right\} \text {. } \\
& \mathrm{RTlna}_{\mathrm{w}}=\Delta G_{\mathrm{f}}^{\circ}\left(\mathrm{WO}_{2}\right)-\mathrm{R}^{\prime} \operatorname{Tln} \mathrm{p}_{02(\mathrm{air})} \\
& +4 \mathrm{FE} \text {. }
\end{aligned}
$$

Ni の活量 aNi は Gibbs-Duhem の式に基づく図積分に より求めた．混合のギブス自由エネルギーは次式により 計算できる。

$$
\Delta G_{\mathrm{m}}=\mathrm{RT}\left(\mathrm{X}_{\mathrm{Ni}} \ln \mathrm{N}_{\mathrm{Ni}}+\mathrm{X}_{\mathrm{w}} \operatorname{lna}_{\mathrm{w}}\right) .
$$

なお, Ni.5 mol\%W 合金試料の場合には，起電力測定 中に試料の焼結が進み，再現性ある起電力值を得にくか ったので，焼結を防止するために試料粉末にジルコニア 粉を添加した。

M相の標準生成ギブス自由エネルギーを求めるために， つぎの電池表式で表される電池を組み立てた。

Cell(V) : $\mathrm{Pt} \mid \mathrm{M}, \mathrm{W}, \mathrm{Ni}-16.4 \mathrm{~mol} \% \mathrm{~W}, \mathrm{~B}_{2} \mathrm{O}_{3}$ |YSZ(8)| air|Pt.

$\mathrm{M}$ 相，W相と平衡する $\mathrm{Ni}-\mathrm{W}$ 固溶体の組成は，1273〜 $1423 \mathrm{~K}$ の温度範囲では実質的に一定であり，それは， Fig. 2 加ら分かるように，83. 6 mol\% Ni-16. 4 mol\%W で，これは $\mathrm{Ni}_{0.836} \mathrm{~W}_{0.164}$ と表されるままた，後述する 
が， M相，W相， $\mathrm{Ni}_{0.836} \mathrm{~W}_{0.164}$ の 3 相亡平衡する酸化物 は $\mathrm{B}_{2} \mathrm{O}_{3}$ である. この電池の電池反応は，

83. $6 \mathrm{NiW}_{2} \mathrm{~B}_{2}+125.4 \mathrm{O}_{2 \text { (a i r ) }}=150.8 \mathrm{~W}$

$$
+100\left(\mathrm{Ni}_{0.836} \mathrm{~W}_{0.164}\right)+83.6 \mathrm{~B}_{2} \mathrm{O}_{3}
$$

である。したがって，M相の標準生成ギブス自由エネル ギーと起電力 $\mathrm{E}$ との間には，つぎの関係がある.

$$
\begin{aligned}
\Delta G_{\mathrm{f}}^{\circ}(\mathrm{M}) & =-(3 / 2) \mathrm{RT}^{\prime} \ln \mathrm{p}_{02(\mathrm{air})} \\
& +(100 / 83.6) \Delta G_{\mathrm{m}}\left(\mathrm{Ni}_{0.836} \mathrm{~W}_{0.164}\right) \\
& +\Delta G^{\circ}{ }_{\mathrm{f}}\left(\mathrm{B}_{2} \mathrm{O}_{3}\right)+6 \mathrm{FE} .
\end{aligned}
$$

$\Delta G_{\mathrm{m}}\left(\mathrm{Ni0.836} \mathrm{W}_{0.164}\right)$ には, Cell(III) と Cell(IV) で求めた

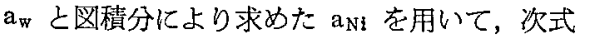

$$
\begin{aligned}
& \Delta G_{\mathrm{f}}^{\circ}\left(\mathrm{Ni}_{0.836} \mathrm{~W}_{0.164}\right)=\mathrm{RT} \\
& \left(0.836 \operatorname{lna}_{\mathrm{Ni}}+0.164 \mathrm{na}_{\mathrm{w}}\right)
\end{aligned}
$$

により計算した值を用いた. $\Delta G^{\circ}{ }^{\circ}\left(\mathrm{B}_{2} \mathrm{O}_{3}\right)$ には, JANAF 熱化学表 ${ }^{17]}$ に記載されている $\mathrm{B}_{2} \mathrm{O}_{3}$ の標準生成ギブス自 由エネルギーの值より算出した次式を用いた。

$$
\Delta G_{\mathrm{f}}^{\circ}\left(\mathrm{B}_{2} \mathrm{O}_{3}\right)=-1232000+216.2 \mathrm{~T} \mathrm{~J} / \mathrm{mol}
$$

本研究の起電力測定温度では $\mathrm{B}_{2} \mathrm{O}_{3}$ は液体であるので, 電極陚料中に $\mathrm{B}_{2} \mathrm{O}_{3}$ が多量に存在すると $\mathrm{YSZ}(8)$ 電解質 が污染され，安定した起電力值が得られない，そこで本 研究では，電極試料作製時に $\mathrm{B}_{2} \mathrm{O}_{3}$ を添加せずに，装置 内に残存する少眰の酸素とホウ化物との反応に上り自然 に生成する $\mathrm{B}_{2} \mathrm{O}_{3}$ を利用するととにした．起電力測定終 了後の電極試料中には，透明な $\mathrm{B}_{2} \mathrm{O}_{3}$ が生成しているて とを確認した.

\section{II -3 電池構造}

起電力測定は，前報沉記載した装置を用いて行った。

\section{III結果と考察}

III-1 M, W, Ni 固溶体と平衡する酸化物相

実験方法の䇢所で記述したようにして作製した試料を X線回折で調べたところ, $\mathrm{WO}_{2}$ の回折ピークは観察され ず, $\mathrm{M}, \mathrm{W}$ および $\mathrm{Ni}$ 固溶体のピークのみが観察された。 さらに，試料を封入した石英管内壁には透明な物質が付 着していた．乙れを純水に溶功たととろ，水溶液は弱 酸性を示した. $\mathrm{B}_{2} \mathrm{O}_{3}$ は透明で非晶質であり，また水に易 溶で，その水溶液は弱酸性である。 また，乙の水溶液を ICP 発光分光分析により定性分析を行い，ホウ素の存 在を確認した。 ニッケルおよびタングステンは検出され なかった。 また, 既述したように, Cell (V) の起電力測 定終了後の電極試料中には，透明な $\mathrm{B}_{2} \mathrm{O}_{3}$ が生成してい るととを確認した，したがって, $\mathrm{M}, \mathrm{W}, \mathrm{Ni}$ 固溶体と平衡 する酸化物相は, $\mathrm{WO}_{2}$ ではなく $\mathrm{B}_{2} \mathrm{O}_{3}$ であると決定した。 III-2 WO $_{2}$ の標準生成ギブス自由エネルギー

Cell (I) の温度と起電力の関係を Fig. 4 に示す. 起 電力之温度の間には良好な直線関係が認められた。最小 2 乗法を適用して求めた直線は,

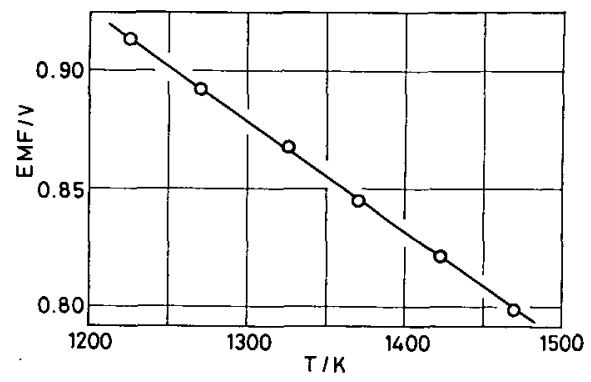

Fig. 4 EMF of cell: $\mathrm{Pt}\left|\mathrm{W}, \mathrm{WO}_{2}\right| \mathrm{YSZ}(8) \mid$ air $\mid \mathrm{Pt}$.

$$
\begin{gathered}
\mathrm{E}=1.485-4.664 \times 10^{-4} T \pm 2 \times 10^{-4} \mathrm{~V} \\
(T=1223 \sim 1473 \mathrm{~K})
\end{gathered}
$$

であった. $\pm 2 \times 10^{-4}$ は直線近似に伴う標準誤差 $\sigma_{\mathrm{E}}(1-$ $\left.\mathrm{r}^{2}\right)^{1 / 2}$ である。， $\sigma_{\mathrm{E}}$ は $\mathrm{E} の$ 標準偏差, $\mathrm{r}$ は相関係数である. このEを式(2)の Eに代入すると, $\mathrm{WO}_{2}$ の標準生成ギブ ス自由エネルギーは，

$$
\begin{gathered}
\Delta G_{\mathrm{f}}^{\circ}\left(\mathrm{WO}_{2}\right)=-573100+167.0 T \pm 100 \mathrm{~J} / \mathrm{mol} \\
(T=1223 \sim 1473 \mathrm{~K})
\end{gathered}
$$

となった. 本研究で得られた $\mathrm{WO}_{2}$ の標準生成ギブス自

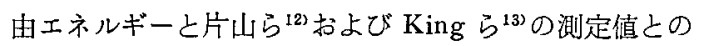
比較を Fig. 5 亿示す. 本研究の結果は片山らおよび King らの測定值と良く一致している.

III-3 WO $\mathrm{WO}_{4 / 18}$ の標準生成ギブス自由エネルギー

Cell( II) の温度と起電力の関係を Fig. 6 亿示す. 起電 力之温度の間には良好な直線関係か認㹱引れ。. 最小 2

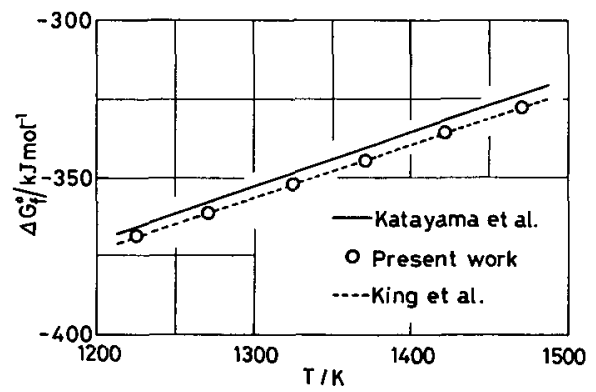

Fig. 5 Standard Gibbs free energy of formation of $\mathrm{WO}_{2}$.

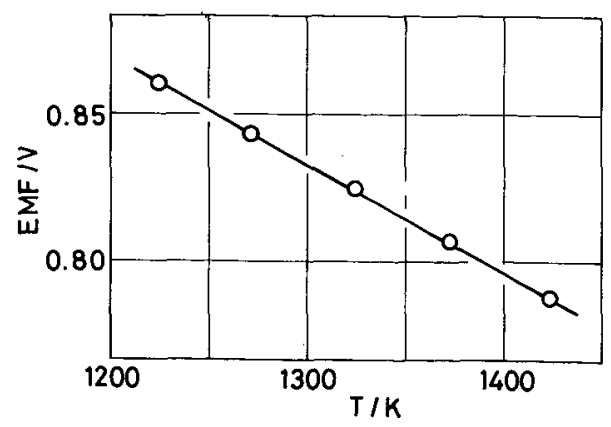

Fig. 6 EMF of cell: $\mathrm{Pt}\left|\mathrm{WO}_{48} / 18, \mathrm{WO}_{2}\right| \mathrm{YSZ}(8)|\operatorname{air}| \mathrm{Pt}$. 


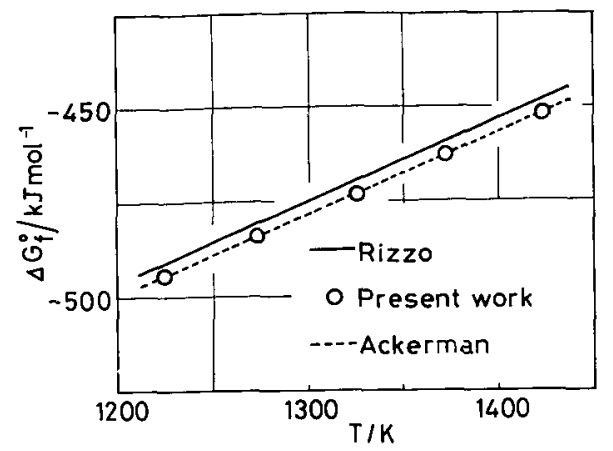

Fig. 7 Standard Gibbs free energy of formation of $\mathrm{WO}_{49} / 18$.

乘法を適用して求めた直線は,

$$
\begin{gathered}
\mathrm{E}=1.308-3.651 \times 10^{-4} T \pm 3 \times 10^{-4} \mathrm{~V} \\
(T=1223 \sim 1423 \mathrm{~K})
\end{gathered}
$$

であった. $\pm 3 \times 10^{-4}$ は直線近似伴う標準誤差である. この Eを式(4)に代入すると， $\mathrm{WO}_{49 / 18}$ の標準生成ギブス 自由エネルギーは,

$$
\begin{gathered}
\Delta G^{\circ}{ }_{\mathrm{f}}\left(\mathrm{WO}_{49 / 18}\right)=-755400+213.2 T \pm 200 \mathrm{~J} / \mathrm{mol} \\
(T=1223 \sim 1423 \mathrm{~K})
\end{gathered}
$$

となった。誤差 $\pm 200 \mathrm{~J} / \mathrm{mol}$ は起電力を直線近似したて とによる誤差 $\pm 40 \mathrm{~J} / \mathrm{mol}$ 亡 $\Delta G_{\mathrm{f}}^{\circ}\left(\mathrm{WO}_{2}\right)$ の誤差 $\pm 100 \mathrm{~J} /$ $\mathrm{mol}$ を考虑して決定した. 本研究で得られた $\mathrm{WO}_{49 / 18}$ の 標準生成ギブス自由エネルギーと Rizzolis および Ackerman $^{15)}$ の测定值との比較を Fig. 7 亿示す. 友研究の 結果は彼等の測定值と良く一致している.

III-4 Ni-W2 成分系の混合のギブス自由エネルギー

Fig. 3 加ら分加る上うに, Ni-W 固溶体と平衡する酸 化物は, $\mathrm{W}$ 濃度が低い場合には $\mathrm{WO}_{49 / 18}$ であり, $\mathrm{W}$ 濃度 が高い場合には $\mathrm{WO}_{2}$ である．したがって，平衡する酸 化物が $\mathrm{WO}_{49 / 18}$ から $\mathrm{WO}_{2}$ へ変わる $\mathrm{Ni}-\mathrm{W}$ 固溶体の組 成を知ることが必要である，そこで， Ni-15. 0 mol\%W 固溶体粉之 $\mathrm{WO}_{2}$ 粉, $\mathrm{Ni}-12.5 \mathrm{~mol} \% \mathrm{oW}$ 固溶体粉之 $\mathrm{WO}_{2}$ 粉, $\mathrm{Ni}-10.0 \mathrm{~mol} \% \mathrm{~W}$ 固溶体粉之 $\mathrm{WO}_{2}$ 粉とを混合し, そ れぞれ正縮成形し, $1273 \mathrm{~K} \sim 1423 \mathrm{~K}$ で熱処理後，X線回 折で平衡する酸化物を同定した. $\mathrm{Ni}-15.0 \mathrm{~mol} \% \mathrm{~W}, \mathrm{Ni}-$ $12.5 \mathrm{~mol} \% \mathrm{~W}$ の場合には，酸化物は配合した $\mathrm{WO}_{2}$ その ままであり， Ni-10.0 mol\%W の場合には，酸化物は WO $_{49 / 18}$ であった. したがって, $1273 \mathrm{~K} \sim 1423 \mathrm{~K}$ の温度 範曲では, $12.5 \mathrm{~mol} \% \mathrm{~W}$ 以上の組成では平衡する酸化物 は $\mathrm{WO}_{2}$ であり, $\mathrm{Ni}-10.0 \mathrm{~mol} \% \mathrm{~W}$ 以下の組成では平衡 する酸化物は $\mathrm{WO}_{49 / 18}$ であると判断した。

Fig. 8 と Fig.9 亿温度之電池の起電力の関係を示す. 起電力は温度に関して直線的に变化した. 式(8)を用い て起電力から計算したWの活量を Table 1 に，またWの 活量から図積分により求めた $\mathrm{Ni}$ の活量を Table 2 に示

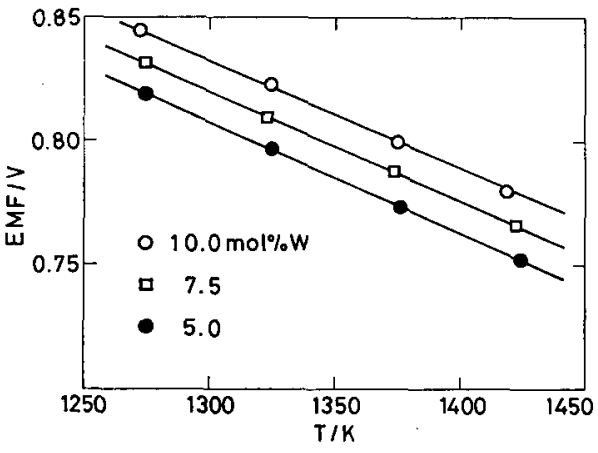

Fig. 8 EMF of cell: $\mathrm{Pt}_{t} \| \mathrm{Ni}-\mathrm{W}, \mathrm{WO}_{49} / 18|\mathrm{YSZ}(8)|$ air $\mid \mathrm{Pt}_{\mathrm{t}}$

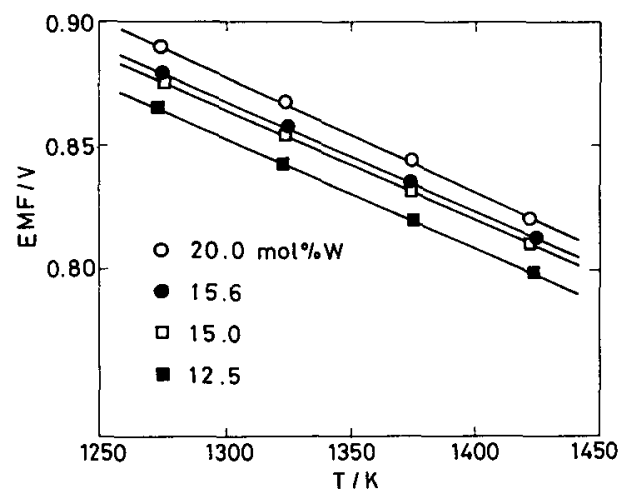

Fig. 9 EMF of cell: $\mathrm{Pt}\left|\mathrm{Ni}-\mathrm{W}, \mathrm{WO}_{2}\right| \mathrm{YSZ}(8)|\mathrm{air}| \mathrm{Pt}$.

す.さらに，Ni とWの活量值を式(9)に代入して求めた $\mathrm{Ni}-\mathrm{W} 2$ 成分系の混合のギブス自由エネルギーを Table 3 亿示す. 起電力值の有效数字は 4 析であったが, $\mathrm{Ni}$ 個 溶体の組成の有效数字が 3 桁程度であったので,Wの活 量の有效数字は 3 桁とした．図積分に伴う $\mathrm{Ni}$ の活量の 誤差は，0.3\%程度と推定されるので, Ni の活瞕の有效 数字古 3 桁とした。したがって，Ni-W 2 成分系の混合 のギブス自由エネルギーの有効数字も 3 桁とした. 式 （11）を用いてM相の標準生成ギブス自由エネルギーを計 算するのに必要な $\mathrm{Ni}-\mathrm{W}$ 固溶体 $(\mathrm{Ni}-16.4 \mathrm{~mol} \% \mathrm{~W})$ の混 合のギブス自由エネルギー $\Delta G_{\mathrm{m}}\left(\mathrm{Ni}_{0.836} \mathrm{~W}_{0.164}\right)$ と温度 の間には良い直線関係か認められた，最小 2 乗法を適用 して求めた直線は,

Table 1 Activity of $\mathrm{W}$ in Ni-W binary alloys.

\begin{tabular}{c|c|c|c|c}
\hline $\mathrm{T}$ & 1273 & 1323 & 1373 & 1423 \\
\hline 0.050 & 0.053 & 0.059 & 0.065 & 0.070 \\
0.075 & 0.101 & 0.110 & 0.120 & 0.130 \\
0.100 & 0.187 & 0.209 & 0.231 & 0.254 \\
0.125 & 0.400 & 0.428 & 0.455 & 0.482 \\
0.150 & 0.594 & 0.633 & 0.672 & 0.709 \\
0.156 & 0.681 & 0.713 & 0.744 & 0.774 \\
0.164 & 1.000 & 1.000 & 1.000 & 1.000 \\
\hline
\end{tabular}


Table 2 Activity of $\mathrm{Ni}$ in Ni-W binary alloys.

\begin{tabular}{c|c|c|c|c}
\hline $\mathrm{T} / \mathrm{K}$ & 1273 & 1323 & 1373 & 1423 \\
\hline 0.050 & 0.948 & 0.946 & 0.946 & 0.945 \\
0.075 & 0.907 & 0.907 & 0.907 & 0.907 \\
0.100 & 0.854 & 0.852 & 0.852 & 0.850 \\
0.125 & 0.775 & 0.778 & 0.782 & 0.785 \\
0.150 & 0.728 & 0.731 & 0.735 & 0.738 \\
0.156 & 0.711 & 0.716 & 0.722 & 0.727 \\
0.164 & 0.660 & 0.671 & 0.682 & 0.692 \\
\hline
\end{tabular}

Table 3 Gibbs free energies of mixing of $\mathrm{Ni}-\mathrm{W}$ binary alloys.

\begin{tabular}{|c|c|c|c|c|}
\hline $\mathrm{x}_{\mathrm{W}}$ & 1273 & 1323 & 1373 & 1423 \\
\hline 0.050 & -2090 & -2140 & -2160 & -2210 \\
\hline 0.075 & -2776 & -2810 & -2850 & -2880 \\
\hline 0.100 & -3280 & -3310 & -3320 & -3350 \\
\hline 0.125 & -3570 & -3580 & -3580 & -3590 \\
\hline 0.150 & -3680 & -3680 & -3670 & -3670 \\
\hline 0.156 & -3680 & -3680 & -3660 & -3660 \\
\hline 0.164 & -3680 & -3670 & -3650 & -3640 \\
\hline
\end{tabular}

$$
\begin{gathered}
\Delta G_{\mathrm{m}}\left(\mathrm{Ni} \mathrm{N}_{836} \mathrm{~W}_{0.164}\right)=-4040+0.280 T \pm 3 \mathrm{~J} / \mathrm{mol} \\
(T=1273 \sim 1423 \mathrm{~K})
\end{gathered}
$$

であった。

\section{III-5 M相の標準生成ギブス自由エネルギー}

Cell (V) の温度と起電力の関係を Fig. 10 に示す. 起 電力は温度に関して直線的に変化した．最小 2 乗法を適 用して求めた $\mathrm{E}$ ～$T$ 関係は，

$$
\begin{gathered}
\mathrm{E}=1.793-4.024 \times 10^{-4} T \pm 2 \times 10^{-4} \mathrm{~V} \\
(T=1273 \sim 1423 \mathrm{~K})
\end{gathered}
$$

であった. $\pm 2 \times 10^{-4}$ は直線近似に伴う標準䛊差である. $1473 \mathrm{~K}$ 以上の温度の起電力值は,上記の值線から大きく 冕れたので，採用しなかった。これは $\mathrm{B}_{2} \mathrm{O}_{3}$ により固体 電解質が污染されたためと考える. 事実, $1473 \mathrm{~K}$ で起電 力測定を行った場合，電解質の内壁は樑さ約 $0.5 \mathrm{~mm}$ ま で白色に変質していた．上記の $\mathrm{E}$ を(11)に代入して求 めた M相の標準生成ギブス自由エネルギーは，

$$
\begin{gathered}
\Delta G_{\mathrm{f}}^{\circ}(\mathrm{M})=-198800+3.076 \mathrm{~T} \mathrm{~J} / \mathrm{mol} \\
(T=1273 \sim 1423 \mathrm{~K})
\end{gathered}
$$

であった．起電力を直線近似したととによる䛊差は $\pm 120 \mathrm{~J} / \mathrm{mol}$ であり, $\Delta G_{\mathrm{m}}\left(\mathrm{Ni}_{0.836} \mathrm{~W}_{0.164}\right)$ の䛊差に由来す る誤差は $\pm 4 \mathrm{~J} / \mathrm{mol}$ である。このほかに, $\Delta G^{\circ}{ }_{\mathrm{f}}\left(B_{2} \mathrm{O}_{3}\right)$ の 䛊差に由来する誤差を考慮しなければならないが，その 值は不明である.そこで, Ni およびWの活量の有効数字 が3桁であったととから考えて，M相の標準生成ギブス 自由エネルギーの有効数字も 3 桁と判断した. したがっ て，M相の標準生成ギブス自由エネルギーは，

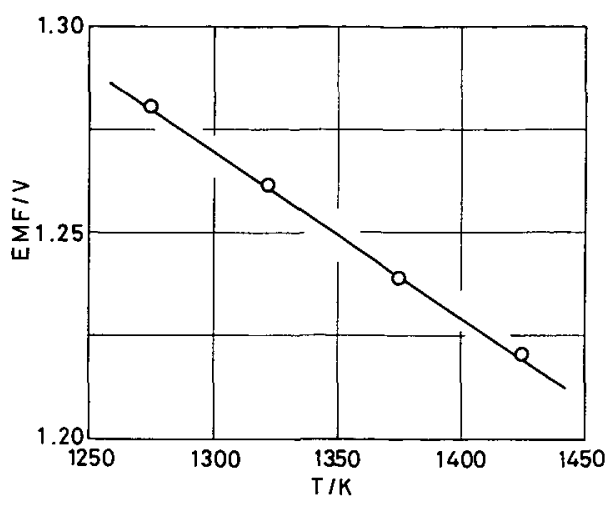

Fig. 10 EMF of cell: $\mathrm{Pt}_{\mathrm{t}} \mid \mathrm{NiW}_{\mathbf{2}} \mathrm{B}_{2}, \mathrm{~W}, \mathrm{Ni}-16.4 \mathrm{~mol} \% \mathrm{~W}$, $\mathrm{B}_{2} \mathrm{O}_{3}|\mathrm{YSZ}(8)|$ air $\mid \mathrm{Pt}$.

$$
\begin{gathered}
\Delta G^{\circ}{ }_{\mathrm{f}}(\mathrm{M})=-199000+3.08 T \pm 1000 \mathrm{~J} / \mathrm{mol} \\
(T=1273 \sim 1423 \mathrm{~K})
\end{gathered}
$$

であると決定した。

\section{III-6 酸素イオンの輸率の検討}

酸化物固体電解質を用いて熱力学諸量の測定を行うた めには，酸素イオンの輸率が実質上 1 と見なせる酸素イ オン伝導領域内で起電力測定を行わねばならない。 Schmaltzried ${ }^{18)}$ によれば, 酸素イオンの輸率 $t_{\text {ion }}$ は次式 で与えられる。

$$
\mathrm{t}_{\mathrm{ion}}=\left[1+\left(\mathrm{p} \theta / \mathrm{p}_{02}\right)^{\mathrm{t} / 4}\right]^{-1}
$$

$\mathrm{p} \theta$ は過剩電子の存在により $\mathrm{t}_{\mathrm{i} \text { on }}=0.5$ になる上きの酸素 分压である. $\mathrm{p} \theta$ は, Iwase ら ${ }^{19}$ によれば，次式で与え られる。

$$
\begin{aligned}
& \log (\mathrm{p} \theta / \mathrm{Pa})-\log (101325) \\
& =18.08-6.24 \times 10^{4} / T
\end{aligned}
$$

$\mathrm{M}$ 相試料極側の平衡酸素分区は，起電力値加ら計算する と, $1273 \mathrm{~K}$ で $1.071 \times 10^{-21} \mathrm{~atm}, 1373 \mathrm{~K}$ で $1.253 \times$ $10^{-19} \mathrm{~atm}$ であり,乙の時の $\mathrm{t}_{\text {ion }}$ をの 2 つの式から計算 すると, それぞれ0.997，0.993となった。 したがって， 本研究の起電力值は, すへて酸素イオン伝導領域で測定 されたすのと見なせる。

\section{$N$ 結 言}

$\mathrm{Ni}-\mathrm{W}-\mathrm{B} 3$ 成分系に存在する $\mathrm{NiW}_{2} \mathrm{~B}_{2}$ 相の標準生成ギ ブス自由エネルギーを，1273〜1423 K の温度範囲で, 酸化物固体電解質を用いる起電力法により測定した。 ま た，乙れを求めるのに必要な $\mathrm{WO}_{2}$ および $\mathrm{WO}_{49 / 18}$ の標 準生成ギブス自由エネルギーおよび $\mathrm{Ni}-\mathrm{W} 2$ 成分系固溶 体の混合のギブス自由エネルギーを測定した．得られた 結果はつぎのとおりである。

(1) $\Delta G^{\circ}{ }^{\circ}\left(\mathrm{NiW}_{2} \mathrm{~B}_{2}\right)=-199000+3.08 T \pm 1000 \mathrm{~J} / \mathrm{mol}$

$$
(T=1273 \sim 1423 \mathrm{~K})
$$


(2) $\Delta G^{\circ}{ }_{\mathrm{f}}\left(\mathrm{WO}_{2}\right)=-573100+167.0 T \pm 100 \mathrm{~J} / \mathrm{mol}$

$$
(T=1223 \sim 1473 \mathrm{~K})
$$

(3) $\Delta G_{\mathrm{f}}^{\mathrm{o}}\left(\mathrm{WO}_{49 / 18}\right)=-755400+213.2 T \pm 200 \mathrm{~J} / \mathrm{mol}$

$$
(T=1223 \sim 1423 \mathrm{~K})
$$

(4) $\mathrm{NiW}_{2} \mathrm{~B}_{2}$ と平衡する $\mathrm{Ni}-\mathrm{W}$ 固溶体 $(16.4 \mathrm{~mol} \% \mathrm{~W})$ の 混合のギブス自由エネルギーは，

$$
\begin{gathered}
\Delta G_{\mathrm{m}}\left(\mathrm{Ni}_{0.836} \mathrm{~W}_{0.164}\right)=-4040+0.280 T \pm 3 \mathrm{~J} / \mathrm{mol} \\
(T=1273 \sim 1423 \mathrm{~K})
\end{gathered}
$$

である.

$$
\text { 文献 }
$$

1）大森，橋本：粉体和上び粉末绐金，20 (1973)，80.

2) 大森, 橋本: 日本金属学会誌, 40 (1976), 601.

3) S. Omori and J. Moriyama: Trans JIM, 21 (1980), 790.

4) 大森, 槅本, 香山：日本金属学会誌，46 (1982)， 760 .

5) 大森, 橋本, 香山: 高温学会誌, 7 (1981), 204.

6) 大森，橋本，香山：日本金属学会誌，45 (1981), 1107.

7) 大森, 橋本, 香山: 高温学会誌, 8 (1982), 221.
8）香山，橋本，鈴木，亀山：日本金属学会誌， 53 (1989), 183.

9）大森，香山，橋本，山下：日本金属学会誌，48(1984), 682.

10) M. Hansen: Constitution of Binary Alloys, 2nd Ed., McGraw-Hill, (1958), p. 1057.

11) K. T. Jacob: J. Mater. Sci, 12 (1977), 1647.

12) I. Katayama and Z. Kozuka: Technol. Rept. Osaka Univ., 23 (1973), 411.

13) E. G. King, W.W. Weller and A. U. Christensen: U.S. Dept. Interior Bur. Mines, Rept. Invest, $\mathbf{5 6 4 4}$ (1960), 1.

14) F. E. Rizzo: Trans. Met. Soc. AIME, 239 (1967), 1901.

15) R. J. Ackerman and E. G. Rauh: J. Phys. Chem., 67 (1963), 2596.

16）日本化学会編：化学便覧基礎編 I, 改定 3版, 丸善, (1984), p. I-22.

17) D. R. Stull and H. Prophet: JANAF Thermochemical Tables, 2nd Ed., U.S. Department of Com. merce, Springfield (1971).

18) H. Schmalzried: Z. Phy. Chem., 38 (1963), 87.

19) M. Iwase, E. Ichise, M. Takeuchi and T. Yamasaki: Trans JIM, 25 (1984), 43.
会 告

\section{第21回高温材料技術講習会}

主 催 : 日本セラミックス協会高温・構造材料部会

共 催：同行事企画委員会

協 賛: 粉体粉末治金協会ほ加

日 時：1990年 2 月 22 日(木) 23 日（金）

会 場 : 日本私学振與財団講堂（千代田区富士見 1-1012, $\operatorname{TEL} 03(230) 1321)$

申込楴切：定員(120名)になり次第

(2月22日)

1. セラミックス成形に打けるレオロジーの役割

（旭硝子）管野 隆志

2. 粉体成形におりる顆粒の役割(名工大) 高橋 実

3. <特別講演>粉体成形技術の基礎

（前京工繊大）荒川 正文

4.ファインセラミックスのコロイドプロセス （コロイドリサーチ）掘誠

5. セラミックスのテーププロセス

（N T K） 浅野 幸泰

6. 八ニカムの押し出し成形 (NGK) 浅見 誠一

7. 新しい複合成形法

(油研工業) 香西 孝
(2月23日)

8. サイクリック CIP によるセラミック粉体の成形

（東工大） 神保 勝久

9. チクソトロピーを利用したアルミナの成形

（産業技術短大）小林 弘旺

10. ネットシェイプ成形技術（N K K） 西尾 浩明

11. 多種小量生産に対応した(スリップキャスト)新成形 プロセス

（新東工業）内村 勝次

12. 新しい鋳込み成形法（香蘭社）栗田 澄彦

13. 大物のスリップキャスト（東陶機器）渡辺信彦

14. セラミックスの高压射出成形

（京工試）斉藤 勝義

15. 低王射出成形（大阪府立産技総研）宫本大樹 参加費 : 主催 - 協賛学協会会員 30,000 円, 学生会員 25,000 円, 非会真35,000円

申込方法 : (1)氏名, (2)勤務先 (广・所在地・電話・所属 部課名), (3)所属学協会名, を明記のうえ参加 費を添えて現金書留で下記あてにで送金下さい

申込先 : $=169$ 新宿区百人町2-22-17 日本セラミックス拹会 高温・構造材料部会 TEL03(362) 5232 